\title{
A Warm Welcome to the ETA Annual Meeting in the Wonderful City of Pisa
}

The 36th Annual Meeting of the European Thyroid Association will be held on September 8-12, 2012 at the Congress Palace in Pisa. At this meeting, the latest developments in the various areas of clinical, basic and translational thyroidology will be presented by internationally renowned researchers. In the afternoon of Saturday, September 8, the annual meeting will be kicked off by Reed Larsen, who will give the European Thyroid Journal Lecture. The meeting will last five days and include a mid-conference field trip.

Keynote speeches and oral presentations by young researchers will be given in the mornings and late afternoons, while the midday hours will be dedicated to poster sessions in which many participants will present their latest research. Several symposia will be held to present an excellent opportunity to learn about major developments in many clinical and basic areas. As the Web continues to expand, making scientific exchange a real-time daily activity, direct contact among researchers remains an irreplaceable need for strengthening the scientific community.

Three satellite conferences will precede the opening of the congress on Saturday: (1) the ICCIDD West Central Europe Regional Meeting, (2) the joint session of European Thyroid Association-Cancer Research Network and European Society of Endocrine Surgeons, and (3) an Italian symposium 'Update in Endocrinology', which will focus on the treatment of Cushing's disease and acromegaly. In addition, a thyroid ultrasound course will be held at the Department of Endocrinology of the University Hospital in Pisa.

Pisa welcomes its visitors with art, cultural events and, of course, the Leaning Tower. The Leaning Tower, however, is not the only unique point of interest Pisa has to offer, as there are many beautiful sites that deserve a visit, including just taking a walk along the historic and picturesque streets. In attending the meeting, you will have the opportunity to enjoy the beauties and spirit of Tuscany during one of the most beautiful times of the year. We have arranged several tours that will allow you to discover and appreciate Pisa.

The welcome reception will take place at the Stazione Leopolda, which was one of the first railway stations built in Italy. It is a large neo-Renaissance building designed by the architect Enrico Presenti, and is named after the HabsburgLorraine Grand Duke Leopold II of Tuscany, who built it in 1844. 
The meeting excursion will allow you to visit the enchanting Charter House of Calci. The monumental Monastery of Calci (Certosa di Calci), just 10 km from Pisa, was founded in 1366 by Carthusian monks. It is today one of the most interesting national museums, exhibiting ancient mineralogical, palaeontological and zoological collections, with some pieces dating back to the 16th century.

The gala dinner will be held at the Cloister of the National Museum of San Matteo, one of the most important European museums in the field of medieval art. It hosts numerous masterpieces of paintings and sculptures from the early Middle Ages, as well as archaeological and ceramic treasures.

We feel sure that ETA 2012 will be a scientifically successful meeting in the friendly and welcoming city of Pisa. We look forward to seeing you here in September 2012.
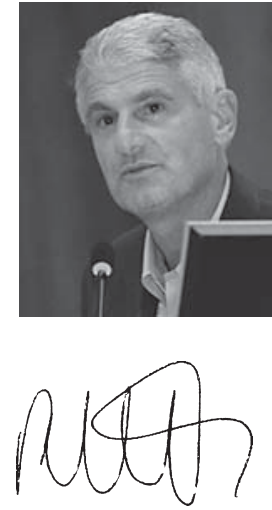

Paolo Vitti

Chair of the Local

Organizing Committee
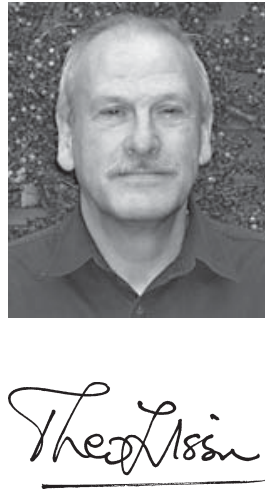

Theo Visser

President of the ETA 